\title{
Student Responses During Online Learning in Biology Subject at SMAN 1 Teluk Keramat, Sambas, West Kalimantan, Indonesia
}

\author{
Nuri Dewi Muldayanti ${ }^{1 *}$, Mahwar Qurbaniah², Rachma Marcella ${ }^{2}$ \\ ${ }^{1}$ Universitas Negeri Yogyakarta, Indonesia \\ ${ }^{2}$ Universitas Muhammadiyah Pontianak, Indonesia \\ *Corresponding author.Email: nuri.dewi@unmuhpnk.ac.id
}

\begin{abstract}
Learning Biology online is an unusual and new thing for students of SMAN 1 Teluk Keramat, which is located in a rural area. This study aimed to evaluate the students' responses toward online learning in Biology at SMAN 1 Teluk Keramat, Sambas, Kalimantan Barat, Indonesia. This study used a quantitative descriptive method conducted in the first semester of the 2020/2021 academic year. The participants were 106 students of XI MIPA (science) class at SMAN 1 Teluk Keramat, Kalimantan Barat, recruited using the disproportionate stratified random sampling. Students' responses were collected using questionnaires and guided interviews and were analyzed using descriptive quantitative based on eleven indicators. The results of the 11 indicators were as follow: the material comprehension was $58.35 \%$, ability to complete assignments $75.92 \%$, independent learning was $62.07 \%$, completion of assignment on time was $65.69 \%$, willingness to learn was $57.85 \%$, learning objectives was $62.25 \%$, learning with pleasure was $59.40 \%$, asking questions was $61.06 \%$, responding to questions was $72.36 \%$, curiosity was $68.48 \%$, and evaluation of learning outcome was $60.11 \%$. In addition, the result also showed that overall, the students' responses were very good during online learning. However, several indicators were not good responses. The result of this study could help teachers evaluate online learning to improve learning process.
\end{abstract}

Keywords: biology learning, students' responses, online learning

\section{INTRODUCTION}

According to the circular letter issued by the Indonesian Minister of Education Number 3 of 2020 concerning Prevention of COVID-19 in Education Units and Number 36962/MPK A/HK of 2020 concerning online learning and working from home to protect the increasing transmission rate of the COVID-19, all form learning of learning was conducted online. According to Fahy [1], the characteristics of online learning are: (1) learning using electronic media; (2) using software or application and internet network; (3) distance learning; (4) the role of media is more dominant in the learning; and (5) online learning requires students' independence. Media devices such as cell phones and computers with large memory storage and a good internet network highly affect how online learning progresses. However, online learning is uncommonly used in Indonesia since the learning is usually done face-to-face. The teachers and the students are not familiar with the online learning system, a newly implemented learning system. According to Sun and Chen [2], to be adequately implemented, those are: (1) a good class design or online learning model; (2) good interaction or communication between teachers and students; and (3) rapid technological development. Technological developments must be proportional to the ability of the teachers and the students to utilize the technology well in learning. Online learning has been implemented for almost a year in Indonesia as a government effort to prevent the spread of COVID-19. However, studying biology online is an uncommon thing and creates problems for students, especially students of SMAN (Public Senior High School) 1 Teluk Keramat, Sambas Regency, Kalimantan Barat, Indonesia, which is located in a rural area. 
Students of SMAN 1 Teluk Keramat are different from students in other districts in Kalimantan Barat, Indonesia, since SMAN 1 Teluk Keramat is located in a rural area in western Indonesia. All learning activities have shifted to computerized techniques by utilizing the internet network, and in the end, as humans being, they are forced to adapt to the situation of technological development. Right now, we have entered the era of revolution 4.0 where all must make maximum use of technology to increase the number of work targets and the quality of time used. Also, the learning system forces them to be implemented optimally while the available facilities are very minimal. Thus, in this study, we investigated students' responses to Biology subjects during online learning. The aim is to evaluate learning outcomes in Biology subjects to improve the quality of education and improve student learning outcomes.

\section{RESEARCH METHOD}

The method in this research consists of research design, population, samples, research instruments, research procedures, and data analysis techniques described as follows.

\subsection{Research Design}

The research method used in was descriptive quantitative which is aimed to describe and explain the object or sample under research through the data that has been collected as it is and making generally accepted conclusions. This research aims to assess student responses to online learning in Biology subjects. The questionnaires were distributed via Google Forms, and the interviews were conducted via WhatsApp.

\subsection{Research Population and Sample}

The population in this research were Science (IPA) students of SMAN 1 Teluk Keramat, Sambas Regency, Kalimantan Barat, Indonesia. The sample in this research was a part of the population used to represent the existing population. In this study, 106 students were selected as the sample.

\subsection{Research Instruments}

The research used two types of instruments: questionnaires and guided interviews. Student responses were measured using a Likert scale consisting of 11 indicators of 22 statements. The 11 indicators are (1) understanding of learning materials, (2) being able to do assignments, (3) self-study, (4) doing assignments from the teacher on time, (5) willingness to learn, (6) learning objectives, (7) learning with pleasure, (8) asking questions, (9) responding to questions, (10) curiosity, (11) evaluation of learning. The response option include 'A' (Always), 'F' (Frequent), 'R' (Rarely) and 'N' (Never)
The questionnaire and interview guidelines must be validated before they can be used, using construct validity and the results of 22 valid statements. Questionnaires and interview guidelines can be used as research instruments. Three lecturers from a team of experts were provided as validators in this research.

The primary data sources in this research were the student responses to questionnaires about online learning in Biology subjects. The secondary data sources in this research were the results of interviews with the students of SMAN 1 Teluk Keramat, Sambas Regency, Kalimantan Barat, Indonesia. Questionnaires were given to the students to determine the level of student responses to online learning in Biology subjects, and interviews were conducted to find out more about how students respond in online learning.

Table 1. Items in the questionnaire about students' responses toward online learning of biology subject

\begin{tabular}{|c|c|c|}
\hline No & Indicator & Statements \\
\hline 1. & $\begin{array}{l}\text { Material } \\
\text { comprehension }\end{array}$ & $\begin{array}{l}\text { Biology subject can be } \\
\text { understood during learning }\end{array}$ \\
\hline 2. & $\begin{array}{l}\text { Ability to } \\
\text { complete } \\
\text { assignments }\end{array}$ & $\begin{array}{l}\text { When given assignments, I can } \\
\text { do them well }\end{array}$ \\
\hline 3. & $\begin{array}{l}\text { Independent } \\
\text { learning }\end{array}$ & $\begin{array}{l}\text { Online learning allows me to } \\
\text { learn independently by reading } \\
\text { more lessons at home }\end{array}$ \\
\hline 4. & $\begin{array}{l}\text { Completion of } \\
\text { assignment on } \\
\text { time }\end{array}$ & $\begin{array}{l}\text { Online learning prevents } \\
\text { students from submitting } \\
\text { assignments on time }\end{array}$ \\
\hline 5. & Willing to learn & $\begin{array}{l}\text { Learning Biology online makes } \\
\text { me less enthusiastic/interested }\end{array}$ \\
\hline 6. & $\begin{array}{l}\text { Knowing study } \\
\text { objectives }\end{array}$ & $\begin{array}{l}\text { Learning objectives can be } \\
\text { achieved when it is done online }\end{array}$ \\
\hline 7. & $\begin{array}{l}\text { Learning with } \\
\text { pleasure }\end{array}$ & $\begin{array}{l}\text { Students do not like learning } \\
\text { Biology online }\end{array}$ \\
\hline 8. & $\begin{array}{l}\text { Asking a } \\
\text { question when } \\
\text { learning }\end{array}$ & $\begin{array}{l}\text { Learning Biology online } \\
\text { encourages me to actively ask } \\
\text { anything I do not understand }\end{array}$ \\
\hline 9. & $\begin{array}{l}\text { Responding to } \\
\text { question }\end{array}$ & $\begin{array}{l}\text { Because I did not understand } \\
\text { the subject, my daily exam } \\
\text { results during the pandemic } \\
\text { dropped. }\end{array}$ \\
\hline 10. & $\begin{array}{l}\text { Curiosity } \\
\text { towards the } \\
\text { subject }\end{array}$ & $\begin{array}{l}\text { Studying biology online } \\
\text { increases my curiosity to learn. }\end{array}$ \\
\hline 11. & $\begin{array}{l}\text { Evaluation of } \\
\text { learning } \\
\text { outcomes }\end{array}$ & $\begin{array}{l}\text { During the pandemic, my daily } \\
\text { exam results were improving }\end{array}$ \\
\hline
\end{tabular}

\subsection{Research procedures}

These research procedures were used to guide the next steps in the investigation of the issues raised. The study started with determining the population and sample size. The following step was to prepare student response instruments in the form of questionnaires and 
guided interview, distributed to students at SMAN 1 Teluk Keramat, Sambas, Kalimantan Barat, Indonesia. The validity test, triangulation, and member check of the instrument were performed after it was finished. The study used instruments that meet the criteria for validity, triangulation, and member check. The study involved the distribution of questionnaires and the interviewing of 106 students. The results of the questionnaire were collected for analysis after it was completed.

\subsection{Data analysis technique}

The study's data was collected through the use of student response questionnaires. This research used a closed questionnaire. The Likert scale was applied in this study. Descriptive statistics are used to analyze the data. The percentage formula was used to assess student answer surveys, in which the students' scores were divided by the maximum score and multiplied by $100 \%$. The average student answer is calculated by dividing the total score by the total number of students. The conversion from percentage to the qualitative category is a modification of calculation, as shown in Table 2.

Table 2. Conversion of student response percentage

\begin{tabular}{|l|l|}
\hline \multicolumn{1}{|c|}{ Percentage } & \multicolumn{1}{c|}{ Response Rate } \\
\hline $81,25<$ NRS $\leq 100 \%$ & Very positive \\
\hline $62,5<$ NRS $\leq 81,25$ & Positive \\
\hline $43,75<$ NRS $\leq 62,5$ & Less positive \\
\hline $25<$ NRS $\leq 43,75$ & Not positive \\
\hline
\end{tabular}

\section{RESULTS AND DISCUSSION}

Descriptive method was used to describe student responses to online learning in biology subjects at SMAN 1 Teluk Keramat.

Table. 3. Percentage of student response regarding questionnaire about learning biology online

\begin{tabular}{|l|l|l|}
\hline Indicators & $(\%)$ & Response Category \\
\hline $\begin{array}{l}\text { Materials } \\
\text { comprehension }\end{array}$ & 58.35 & Less positive \\
\hline $\begin{array}{l}\text { Ability to complete } \\
\text { assignments }\end{array}$ & 75.92 & Positive \\
\hline Independent learning & 62.07 & Positive \\
\hline $\begin{array}{l}\text { Completion of } \\
\text { assignments on time }\end{array}$ & 65.69 & Positive \\
\hline Willingness to learn & 57.85 & Less positive \\
\hline Learning objectives & 62.25 & Less positive \\
\hline $\begin{array}{l}\text { Learning with } \\
\text { pleasure }\end{array}$ & 59.40 & Less positive \\
\hline Asking questions & 61.06 & Less positive \\
\hline $\begin{array}{l}\text { Responding } \\
\text { questions }\end{array}$ & 72.36 & Positive \\
\hline Curiosity & 68.48 & Positive \\
\hline $\begin{array}{l}\text { Evaluation of } \\
\text { learning outcomes }\end{array}$ & 60.11 & Less positive \\
\hline Average Percentage & $\mathbf{6 3 . 9 5}$ & Positive \\
\hline
\end{tabular}

\subsection{Materials comprehension}

Materials comprehension indicator reached a percentage of $58.35 \%$, so that it was categorized as the less positive response. These findings suggest that students find face-to-face learning more effective than online learning in terms of comprehending learning materials.

Empirically, students had trouble understanding learning materials during online learning. Several factors contributed to this, including a lack of internet quotas to join online classes, a limited internet network, difficult-to-understand material, a lack of focus on learning, students who were not used to independent learning, a lack of discussion between students and teachers, and difficulties with practice. These empirical findings resulted in a less positive student response.

\subsection{Ability to complete assignments}

This indicator reached $75,92 \%$, which means it was categorized as a positive response. These findings suggest that during online learning, students find it is easier to finish assignments compared to face-to-face learning. There were various reasons why students chose to complete projects online rather than in person. Actively searching on Google was faster and easier to access; activities might be completed anywhere and at any time; doing tasks can be more relaxed, flexible, and it could be accessed at any time.

Those findings suggest a positive student response. However, it should be mentioned that students' favorable responses were based on the obligation to submit the assignments rather than on knowledge gained when doing those assignments since failing to submit assignments will impact the grade given by their teachers.

\subsection{Independent learning}

The response in the independent learning indicator was less positive, with a percentage of $62.07 \%$. This demonstrates that students have difficulties with independent learning while learning online, implying that when they learn face-to-face, they need to be observed directly by the teacher. Students were less independent during online learning because of various reasons, including difficulty in understanding the topic, being lazy when studying because there was no direct supervision of students, students were not used to selfstudy, and their IT abilities were still inadequate. Because of these factors, online student self-study was less favorable.

\subsection{Completion of assignments on time}

On assignment completion on time indicator, the percentage was $65.69 \%$ which indicated a positive response. This proves that students in online learning can submit their assignments on time. Factors that influenced students to complete the assignments on time 
were that they could easily obtain the answer on Google, saving time and effort. Besides, it could be submitted anywhere and at any time. However, this study could not measure whether the task was being completed by the student or by someone else. These findings should be noted to the teacher.

\subsection{Willingness to learn}

This indicator reached $57.85 \%$, showing a less positive response. This demonstrates that students' motivation to learn is low during online learning. Several factors that contributed to students' unwillingness to learn during online learning were: Learning biology online was difficult because the material was difficult to understand, causing students to be lazy in their learning. The internet network, particularly in rural areas, was less stable. Lack of interaction between students and teachers, resulting in one-way learning. The desire or awareness to learn has a significant influence on student interest in learning because if students do not have the desire to learn, then what is taught will be useless [3].

\subsection{Learning objectives}

The learning objectives indicator obtained a percentage of $62.25 \%$, indicating a less positive response. Students believe that online learning prevents them from achieving their learning objectives. Because some biological materials were harder to comprehend online, the objective of understanding all of the content was not met. This becomes a reminder to teachers to be innovative in their curriculum presentation that the material offered was sometimes not clear, making direct two-way communication difficult. According to Suwarni [4], the learning process is said to be successful if there is a structuring of changes from students' cognitive, affective, and psychomotor aspects, and success in the teaching and learning process to achieve learning objectives necessarily involves the use of appropriate learning methods.

\subsection{Learn with pleasure}

On the indicator of learning with pleasure, it obtained a percentage of $59.40 \%$, so it is categorized as a less positive response. Students believe that learning biology online is not a pleasant experience, because sometimes the internet connection/network was suddenly weak/disturbed, so the activity depended a lot on their signal strength and internet quota. Other factors are difficulty in understanding materials, lack of discussions between students and teachers because they only used WhatsApp group chat. Learning is an activity that a person engages in gaining competence in necessary skills and knowledge [5]. Learning can also be viewed as a process of elaboration in a person's search for meaning. The goal of the learning process is to increase professional talents or competencies. Students are more encouraged to have high motivation in learning in the context of fun learning by generating interesting and exciting situations.

\subsection{Asking question}

This indicator reached $61.06 \%$ and is categorized as a less positive response. It means, during learning biology online, students were unwilling to ask questions, even if some of the contents were unclear. Factors contributing to this were students no longer had a desire to study, did not enjoy online learning, no longer prioritized the learning objectives, and were merely fulfilling their responsibility as students. Students were not actively asking because they were unsure of what to ask. According to Cahyani [6], asking questions is a crucial part of the learning process since it allows students to have the subject explained again if they don't understand it. According to Yeni [7], the more information students have, the more questions they ask and vice versa.

\subsection{Responding question}

The percentage reached was $72.36 \%$ on responding questions indicators, indicating a positive response. This means that during learning biology online, students were able to respond to the teacher's questions. Asking questions reflects curiosity, whereas answering questions describes a person's ability to think. However, some students probably only responded to questions to appear as active students to gain additional points. Even though asking questions was teachers' way to encourage their students to think, it should be noted that only a few of the students were actively answering, and mostly the students who kept asking were the same ones over some meetings.

\subsection{Curiosity}

The percentage in the curiosity indicator was 68.48 percent, categorized in the positive response. This indicates that students are interested in biological lessons delivered through online learning. Curiosity, according to[8], is the starting point for knowledge. Curiosity arises when students believe that what they are learning is something new that must be known to answer their ignorance. Meanwhile, Silmi and Kusmarni [9] stated that curiosity is a natural emotion in humans when there is a desire to investigate and learn more about something they are learning. Curiosity will drive students to learn more about what they don't know; by learning, students will gain a range of new information and knowledge to support their existing knowledge.

\subsection{Evaluation of learning}

The learning evaluation indicator gained a percentage of $60.11 \%$, categorized as a less positive response. This means that when some students' daily tests, mid-semester exams, and final semester exams scores decrease, others' grades improve. Based on the findings, students' enthusiasm or interest in solving online questions was low, student participation in the learning process was low because not all students were 
enrolled in online classes, learning hours were reduced, teachers' and students' technological skills were mostly suboptimal, final grades only based on the assessment of assignments and answering questions, rural internet networks were poor, and quotas are limited. According to [10], the evaluation during the pandemic was not performed under the usual rules and guidelines in terms of cognitive, affective, and psychomotor aspects.

\section{CONCLUSION}

Because of the lack of interaction with other students or lecturers, students spent less time studying online. Teachers increasingly used the WhatsApp group chat program in the classrooms to customize lessons according to students' interests. As a result, it was difficult for students and teachers to keep track of what they were learning. Learning biology online has its own set of challenges for students, such as a lack of comprehension and initiative to learn independently, inability to comprehend module contents and books, students relying only on teacher instructions, and the sole objective of online learning was to achieve marks. As a result, students in SMAN 1 Teluk Keramat, Sambas regency, Kalimantan Barat, Indonesia, preferred face-to-face learning over online learning.

\section{AUTHORS’ CONTRIBUTIONS}

NDM dan RM contributed to the design of the assessment model, data collection, and interpretation of the results. NDM contributed to model supervision. RM contributed to conducting the content validation. NDM contributed to supervising data analysis

\section{.ACKNOWLEDGMENTS}

I would like to acknowledge and give my warmest thanks to my supervisor Raudhaltul Fhadillah who made this project possible. Her guidance and advice carried through all the stage writing this project.

\section{REFERENCES}

[1] P. J. Fahy, "Characteristics of Interactive Online Learning Media." AU Press Athabasca university, canada, 2004, pp. 179-212. [Online]. Available: file://C:/Users/user/Downloads/artikel fahy.html.

[2] A. Sun and X. Chen, "Online education and its effective practice: A research review," J. Inf. Technol. Educ. Res., vol. 15, no. 2016, pp. 157190, 2016, DOI: 10.28945/3502.

[3] S. Budiwibowo, "Hubungan Minat Belajar Siswa Dengan Hasil Belajar Ips Di Smp Negeri 14 Kota Madiun," GulawentahJurnal Stud. Sos., vol. 1, no. 1, p. 60, 2016, DOI: 10.25273/gulawentah.v1i1.66.
[4] D. I. Suwarni, S. Kurniasih, and R. T. Rostikawati, "Penerapan model pembelajaran think-talk-write (TTW) dan demonstrasi reciprocal untuk meningkatkan hasil belajar ekosistem Siswa SMP PGRI Suryakencana Cileungsi Kabupaten Bogor,' J. Pendidik. Ilm., vol. 3, no. 3, 2018, pp. 90-95.

[5] Z. Trinova, "Hakikat Belajar Dan Bermain Menyenangkan Bagi Peserta Didik," Al-Ta lim J., vol. 19, no. 3, 2012, pp. 209-215. DOI: 10.15548/jt.v19i3.55.

[6] P. A. H. I. Cahyani, I. G. Nurjaya, and S. A. P. Sriasih, "Analisis keterampilan bertanya guru dan siswa dalam pembelajaran bahasa Indonesia di Kelas X TAV 1 SMK Negeri 3 Singaraja," eJuornal Univ. Pendidik. Ganesha, vol. 3, no. 1, 2015, pp. 1-12. [Online]. Available: http://dx.doi.org/10.23887/jjpbs.v3i1.7204.

[7] Y. N. prilanita dan Sukirno, "Peningkatan Ketrampilan Bertanya siswa Melalui Faktor Pembentuknya," Cakrawala Pendidik., no. 2, 2017, pp. 244-256. [Online]. Available: https://journal.uny.ac.id/index.php/cp/article/view/ 11223.

[8] B. M. Mydha Tri Puspitasari, Sigit Santoso, "Upaya Meningkatkan Karakter Rasa Ingin Tahu Dan Hasil Belajar Akuntansi Melalui Pembelajaran Kontekstual Dengan Metode Snowball Throwing Pada Siswa Smk Muhammadiyah 3 Gemolong," J. Tata arta UNS, vol. 1, no. 1, 2015, pp. 31-39. [Online]. Available: file:///D:/artikel CICEE/artikel puspitasari.pdf.

[9] M. Silmi and Y. Kusmarni, "Menumbuhkan Karakter Rasa Ingin Tahu Siswa Dalam Pembelajaran Sejarah Melalui Media Puzzle," FACTUM J. Sej. dan Pendidik. Sej., vol. 6, no. 2, 2017, pp. 230-242. DOI: 10.17509/factum.v6i2.9980.

[10] M. Fitrah and Ruslan, "Eksplorasi Sistem Pelaksanaan Evaluasi Pembelajaran di Sekolah pada Masa Pandemi Covid-19 di Bima," vol. 5, no. 1, 2021, pp. 178-187. 